\title{
PENINGKATAN KETERAMPILAN BUDIDAYA TERNAK UNGGAS BAGI PETERNAK AYAM LOKAL DI KABUPATEN KOLAKA MELALUI BIMBINGAN TEKNIS INSEMINASI BUATAN DAN METODE PERSILANGAN
}

\section{IMPROVING SKILLS OF POULTRY CULTIVATION FOR LOCAL CHICKEN FARMERS IN KOLAKA DISTRICT THROUGH TECHNICAL GUIDANCE OF ARTIFICIAL INSEMINATION AND CROSSING METHODS}

\author{
Junaedi $^{1^{*}}$, Khaeruddin ${ }^{2}$, Abdul Hakim Fattah ${ }^{2}$ \\ ${ }^{1}$ Bagian Peternakan, Fakultas Pertanian Perikanan dan Peternakan, \\ Universitas Sembilanbelas November, Kolaka. \\ ${ }^{2}$ Program Studi Peternakan, Fakultas Sains dan Teknologi, Universitas Muhammadiyah Sinjai \\ *Email: junaedi.peternakan@gmail.com \\ (Diterima 04-02-2021; Disetujui 23-03-2021)
}

\begin{abstract}
ABSTRAK
Ayam lokal merupakan jenis ayam bukan ras (buras) Indonesia yang keberadaannya masih belum sepenuhnya mendapatkan perhatian dari usaha pembibitan sehingga produktivitasnya masih tergolong rendah. Peningkatan produktivitas ayam local dapat dilakukan dengan program persilangan pada pemeliharaan sistem intensif. Sistem perkawinan buatan (inseminasi buatan) pada pemeliharaan sistem intensif cukup efektif dilakukan karena cukup efisien dalam penggunaan jumlah pejantan. Peternak ayam lokal di Kabupaten Kolaka belum menerapkan metode inseminasi buatan dan upaya persilangan pada ternak unggas mereka. Hal ini mendorong penulis melakukan kegiatan pengabdian kepada masyarakat yang bertujuan untuk meningkatkan pengetahuan dan keterampilan bagi peternak ayam lokal di Kecamatan Watubangga Kabupaten Kolaka terkait penerapan teknologi inseminasi buatan (IB) pada unggas. Rangkaian kegiatan meliputi: 1) Membuat Rencana Kegiatan Bimtek IB pada Unggas, 2) Membuat panduan tentang inseminasi buatan (IB) pada unggas, 3) Merancang alat IB unggas, 4) Mendemonstrasikan teknik IB ayam, dan 5) Evaluasi hasil praktek IB ayam. Bimbingan teknis dilakukan terhadap 8 peternak ayam lokal di Kecamatan Watubangga Kabupaten Kolaka. Terjadi peningkatan pengetahuan masyarakat mengenai inseminasi buatan pada unggas setelah dilakukan bimbingan teknis yang ditandai dengan peningkatan nilai pemahaman rata-rata $50 \%$.
\end{abstract}

Kata Kunci: Inseminasi Buatan, Ayam Lokal, Kabupaten Kolaka, Persilangan

\section{ABSTRACT}

Local chickens are a type of non-purebred chicken in Indonesia, whose existence has not received full attention from the breeding business so that their productivity is still low. Increasing the productivity of local chickens can be done with a cross-breeding program in intensive system maintenance. The artificial mating system (artificial insemination) in intensive system maintenance is quite effective because it is quite efficient in using the number of males. Local chicken farmers in Kolaka Regency have not applied artificial insemination methods and crossbreeding efforts on their poultry. This encourages the authors to carry out community service activities aimed at increasing knowledge and skills for local chicken breeders in Watubangga District, Kolaka Regency regarding the application of artificial insemination (AI) technology in poultry. The series of activities include: 1) Creating a AI techical guidance activity Plan for Poultry, 2) Making a guide on artificial insemination in poultry, 3) Designing avian AI equipment, 4) Demonstrating the chicken AI technique, 5) Evaluating the results of the chicken AI practice. Technical guidance was carried out for 8 local chicken breeders in Watubangga District, Kolaka Regency. There was an increase in public knowledge about artificial insemination in poultry after technical guidance was carried out which was marked by an increase in the understanding value by an average of 50\%.

Keywords: Artificial Insemination, Local Chickens, Kolaka Regency, Crossing 
Peningkatan Keterampilan Budidaya Ternak Unggas Bagi Peternak Ayam Lokal di Kabupaten Kolaka Melalui Bimbingan Teknis Inseminasi Buatan dan Metode Persilangan

Junaedi, Khaeruddin, Abdul Hakim Fattah

\section{PENDAHULUAN}

Kebutuhan konsumsi daging nasional cenderung meningkat setiap tahunnya. Oleh karena itu, dibutuhkan peningkatan populasi ternak terutama ternak unggas melalui ketercukupan penyediaan bibit baik dari segi kualitas maupun kuantitasnya. Upaya pengembangbiakan ternak ayam pada umumnya masih menggunakan cara konvensional, yaitu melalui perkawinan secara alam. Campur tangan oleh peternak dalam hal sistem perkawinan ini masih sangat minim, sehingga efisiensi produksi rendah dan memberikan peluang terjadinya inbreeding yang relatif tinggi. Dampaknya akan menurunkan kemampuan produksi, dimana pertumbuhan lambat dan produksi telur makin menurun bagi generasi berikutnya.

Pemeliharaan ayam secara intensif yang dilakukan pada kandang individual, seekor pejantan hanya dapat melakukan kawin alam secara bergiliran dari suatu kandang ke kandang yang lain. Disamping itu, untuk pengadaan telur tetas sebagai sumber bibit ayam untuk peremajaan masih merupakan suatu kendala melalui perkawinan secara alam, karena memerlukan pejantan unggul dalam jumlah yang banyak. Hal ini dapat memperbesar biaya produksi untuk pemeliharaan pejantan. Untuk mengatasi kendala tersebut, salah satu alternatif yang dapat dilakukan yaitu dengan penerapan bioteknologi dalam bidang reproduksi ternak dengan penerapan teknologi Inseminasi Buatan (IB) pada ayam. Dengan cara ini semen dari seekor pejantan dapat diencerkan untuk mengawini sekitar tujuh belas ekor betina.

Inseminasi buatan pada unggas merupakan salah satu teknologi yang diharapkan dapat memperbaiki produktivitas ayam, dan merupakan teknik yang berharga dalam industri peternakan unggas maupun dalam riset penelitian. Dengan sistem ini dapat diprogramkan upaya untuk mendapatkan bibit dan DOC (day old chick) dalam jumlah banyak dengan umur sama dalam waktu pendek. Ayam lokal merupakan jenis ayam bukan ras (buras) Indonesia yang keberadaannya masih belum sepenuhnya mendapatkan perhatian dari usaha pembibitan sehingga produktivitasnya masih tergolong rendah. Peningkatan produktivitas ayam lokal dapat dilakukan dengan program persilangan pada pemeliharaan sistem intensif. Sistem perkawinan buatan (inseminasi buatan) pada pemeliharaan sistem intensif cukup efektif dilakukan karena cukup efisien dalam penggunaan jumlah pejantan.

Suprijatna et al (2012) menyatakan bahwa ke depan diperkirakan permintaan ayam buras sebagai ayam lokal akan terus meningkat dan tidak akan menutup kemungkinan terjadi pengurasan bibit. Populasi ayam buras di Kecamatan Watubangga jauh lebih tinggi 
dibandingkan ayam ras dengan jumlah 109.964 ekor (Badan Pusat Statistik Kabupaten Kolaka, 2016), sehingga daerah ini cukup berpotensi untuk pengembangan ayam buras. Peternak ayam lokal di Kabupaten Kolaka belum menerapkan metode inseminasi buatan dan upaya persilangan pada ternak unggas mereka. Hal ini disebabkan kurangnya pengetahuan dan keterampilan peternak tentang penerapan inseminasi buatan pada unggas. Untuk mengatasi hal tersebut, maka dilakukan kegiatan bimbingan teknis inseminasi buatan pada ayam lokal. Tujuan kegiatan pengabdian masyarakat ini adalah untuk meningkatkan pengetahuan dan keterampilan bagi peternak ayam lokal terkait penerapan teknologi inseminasi buatan pada unggas di Kecamatan Watubangga Kabupaten Kolaka.

\section{BAHAN DAN METODE}

\section{Lokasi, Waktu dan Partisipasi Kegiatan}

Pelaksanaan aktualisasi dimulai pada tanggal 16 Februari hingga 20 Februari 2021. Bimbingan teknis dilakukan terhadap 8 peternak ayam lokal di Dusun III Anggalomeura, Desa Kokutio, Kecamatan Watubangga, Kabupaten Kolaka, Provinsi Sulawesi Tenggara.

\section{Bahan dan Alat}

Peralatan yang digunakan untuk bimbingan teknis IB yaitu spuit tuberculin $1 \mathrm{ml}$, tabung eppendorf, selang kateter dan gunting. Sedangkan bahan yang digunakan, yaitu Ringer laktat, ayam pejantan berumur minimal 1 tahun dan ayam betina.

\section{Metode Pelaksanaan Kegiatan}

Metode pelaksanaan mencakup 5 kegiatan utama, yaitu:

1. Pembuatan Rencana Kegiatan Bimbingan Teknis (Bimtek) IB pada Unggas Meliputi kegiatan mencari literatur dan mencatat literatur. Kegiatan tersebut bertujuan untuk membuat poin-poin materi pembuatan buku panduan IB pada unggas.

2. Pembuatan panduan tentang inseminasi buatan (IB) pada unggas Pembuatan buku tersebut berfungsi sebagai alat bantu bagi peternak ayam lokal untuk mengetahui langkah-langkah dalam rangkaian teknik IB yang meliputi pengenalan organ reproduksi ayam indukan dan pejantan, kriteria indukan dan pejantan yang layak di IB, teknik koleksi semen pada ayam pejantan dengan metode pengurutan (massage), serta teknik inseminasi pada ayam betina.dengan metode intrauteri. 
Peningkatan Keterampilan Budidaya Ternak Unggas Bagi Peternak Ayam Lokal di Kabupaten Kolaka Melalui Bimbingan Teknis Inseminasi Buatan dan Metode Persilangan

Junaedi, Khaeruddin, Abdul Hakim Fattah

3. Persiapan alat IB unggas

Kegiatan ini berupa pengumpulan alat-alat inseminasi yang dapat digunakan untuk metode intrauteri.

4. Demonstrasi teknik IB ayam

Kegiatan ini diawali dengan demonstrasi teknik koleksi semen dengan metode pengurutan (massage). Dilanjutkan dengan teknik pengenceran semen, dan diakhiri dengan demonstrasi teknik inseminasi buatan dengan metode intrauterine.

5. Evaluasi hasil praktek IB ayam.

Kegiatan ini beertujuan untuk mendapatkan tingkat pemahaman peternak ayam lokal sebelum dilakukan bimtek dan setelah mendapatkan bimbingan. Partisipan diberikan soal ujian sebelum, dan setelah kegiatan bimbingan teknis, kemudian diberikan nilai. Analisis uji t digunakan untuk mengetahui perbedaan pengetahuan peternak sebelum dan setelah kegiatan.

Hasil evaluasi peternak ayam lokal peserta bimtek akan menjadi acuan bagi penulis dalam menilai keberhasilan program bimbingan tekhnis IB pada unggas bagi peternak ayam lokal.

6. Program persilangan ayam

Melakukan pembimbingan untuk program persilangan ayam lokal dalam rangka peningkatan mutu genetik ayam lokal di Kabupaten Kolaka

\section{HASIL DAN PEMBAHASAN}

\section{Tahap Pemilihan dan Persiapan Bibit Untuk IB}

Bibit induk betina yang digunakan harus memenuhi kriteria, yaitu sehat dan tidak cacat, berproduksi tinggi, minimal sudah mengalami periode peneluran pertama, umur 7-8 bulan, induk betina sedang bertelur, dan pemeliharaan induk dalam kandang individu. Bibit pejantan harus memenuhi persyaratan, yaitu, sehat, lincah dan memiliki nafsu kawin yang tinggi, umur 1-3 tahun, memiliki mutu genetik yang tinggi, mempunyai hubungan genetik yang jauh dengan induk yang akan diinseminasi, dan telah terlatih ditampung semennya. Menurut Iskandar (2007), koleksi semen dapat dilakukan melalui tahapan latihan dua sampai tiga kali pemerahan sebelum dilakukan penampungan semen.

Kandang pemeliharaan pejantan harus terpisah dengan induk dan menggunakan kandang individu. Menurut Iskandar (2007), ayam pejantan sumber semen sebaiknya dikurung dalam kandang berukuran cukup besar untuk dapat mengepakkan sayap dan berkokok dengan ukuran 40 × 50 × $60 \mathrm{~cm}$. Persiapan bibit dilakukan dengan pemberian 
pakan untuk pejantan harus yang baik mutunya dengan kadar protein minimal 17\%, pemberian anti stress untuk induk dan pejantan, serta mencukur bulu di sekitar kloaka untuk memudahkan dalam melaksanakan IB.

\section{Koleksi Semen Ayam}

Koleksi (pengambilan) semen dilakukan oleh 2 orang (satu orang memegang dan mengurut ayam, sementara yang lain menampung semen dengan tabung/spuit penampung semen). Pengambilan semen dilakukan 3-5 kali seminggu pada sore hari setelah pukul 15.30 karena pada saat itu diperkirakan ayam telah bertelur sehingga gerakan spermatozoa tidak mengalami hambatan karena pada saat itu belum terjadi peletakan telur (oviposisi).

Pengkoleksian semen dilakukan oleh 2 orang, 1 orang bertugas memegang ayam (orang yang akan mengeluarkan semen), dan 1 orang lainnya bertugas menampung semen. Ayam jantan diapit diantara lengan dan badan, orang yang bertugas mengeluarkan semen, satu tangan digunakan untuk mengurut (massage), dan tangan yang satu memegang kedua kaki ayam jantan. Koleksi semen dilakukan dengan menggunakan metode pengurutan (massage) pada bagian bawah tulang pubis dari ternak jantan. Pengurutan dilakukan dari muka ke belakang sambil mengangkat ekor dan mengadakan sedikit tekanan pada bagian akhir phallus untuk menimbulkan refleks ejakulatoris. Pemijatan dilakukan beberapa kali (5-7 kali) secara cepat dan kontinyu sampai pejantan memberi respon dengan mengeluarkan papilae. Setelah papilae keluar, jari telunjuk menekan bagian bawah tulang pubis, dengan rangsangan tersebut ayam akan reaksi, ditandai dengan meregangnya bulu ekor ke atas, dan pada saat yang bersamaan tekan bagian bawah ekor maka alat kelamin akan mengeluarkan sperma berwarna putih agak kental. Saat terjadi ejakulasi, semen yang keluar segera ditampung oleh orang kedua. Penampungan semen pada ayam jantan bisa dilakukan 2-3 kali seminggu.

\section{Pengenceran Semen}

Ringer laktat dicampurkan dengan semen dengan perbandingan semen dan ringer laktat adalah 1:6-10. Mengocok secara perlahan membentuk pola angka 8 hingga tercampur merata. Semen yang telah diencerkan siap untuk diinseminasikan ke ayam betina. Dosis inseminasi untuk satu ekor ayam betina adalah $0,3-0,5 \mathrm{ml}$. 
Peningkatan Keterampilan Budidaya Ternak Unggas Bagi Peternak Ayam Lokal di Kabupaten Kolaka Melalui Bimbingan Teknis Inseminasi Buatan dan Metode Persilangan

Junaedi, Khaeruddin, Abdul Hakim Fattah

\section{Inseminasi pada Ayam Betina}

Inseminasi Buatan pada ayam dilakukan dengan metode intra uterin, artinya semen yang telah diencerkan dimasukkan ke bagian uterus dengan kedalaman $\pm 7-8 \mathrm{~cm}$. Keuntungan IB dengan metode deposisi intra uterine adalah selain mengurangi stress, sperma langsung didepositkan ke daerah UVJ. Setelah dikondisikan, spermatozoa yang normal dan memiliki motilitas yang progresif akan bergerak cepat dengan bantuan rheotaksis yaitu pergerakan yang berlawanan dengan aliran cairan menuju infundibulum dan disimpan dalam sperm nest untuk menunggu proses pembuahan (fertilisasi).

Pelaksanaan inseminasi buatan dilakukan 2 orang, dimana 1 orang memegang ayam dan 1 orang melaksanakan inseminasi. Ayam betina yang akan diinseminasi dilakukan pembersihan kotoran yang menempel di anus dan sekitarnya dengan menggunakan tissu. Menyiapkan syringe spuit yang ujungnya disambung dengan selang kateter sepanjang 7-8 $\mathrm{cm}$ (intra uterin). Tekan bagian tubuh di bawah anus hingga terlihat saluran reproduksi (sebelah kiri) dan saluran kotoran (sebelah kanan). Semen yang sudah diencerkan disedot dengan spuit tanpa jarum sebanyak 0,3-0,5 $\mathrm{ml}$ kemudian dimasukan ke dalam uterus ayam yang berada di saluran sebelah kiri sedalam 7-8 cm (intra uterin). Menyemprotkan semen dengan menekan syringe spuit dengan dosis $0,3-0,5 \mathrm{~mL}$ dengan konsentrasi spermatozoa minimal 100 juta sel. Untuk mendapatkan hasil yang baik, sebaiknya Inseminasi Buatan diulang 3 hari setelah Inseminasi Buatan yang sebelumnya untuk menghasilkan fertilitas yang maksimal. Penelitian Irastuti (2011) menyebutkan bahwa fertilitas telur ayam buras dengan interval IB 3 hari sekali sebesar 70,83\%. Kismiati (1999) melaporkan bahwa interval IB 15 hari hanya menghasilkan fertilitas $54.43 \%$.

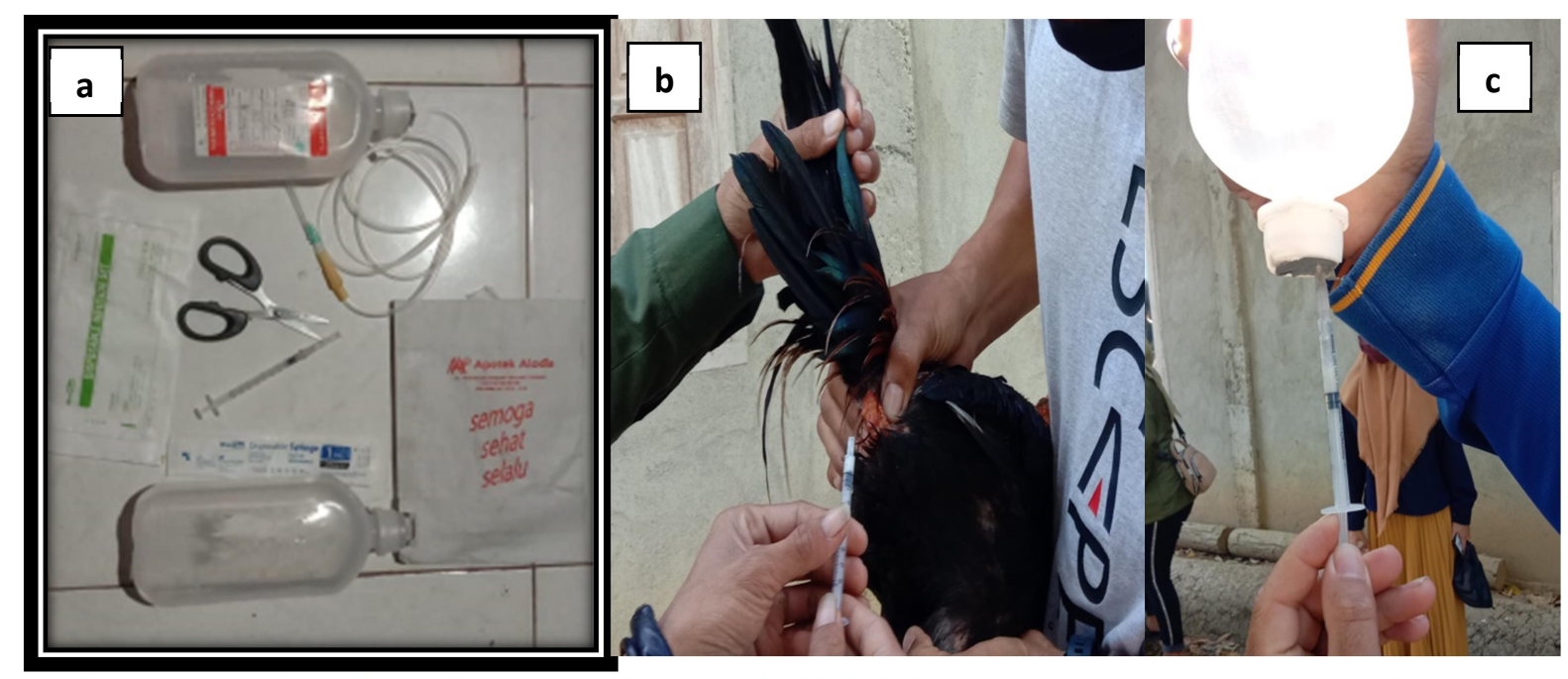

Gambar 1.a. Peralatan inseminasi buatan, b. Koleksi semen, dan c. Pengenceran Semen 

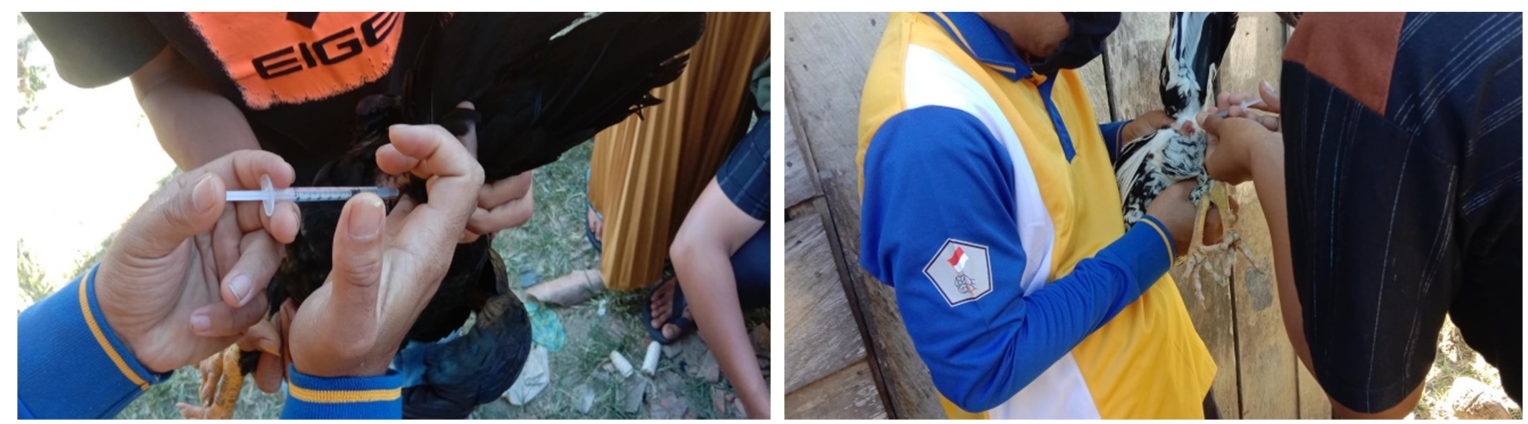

Gambar 2. Inseminasi buatan pada ayam betina

\section{Hasil Analisis Kemampuan Peternak Sebelum dan Setelah Bimtek IB pada Unggas}

Hasil evaluasi nilai ujian sebelum bimbingan teknis rata-rata 38.75 sedangkan nilai ujian setelah bimbingan teknis 88.75 (Gambar 3)

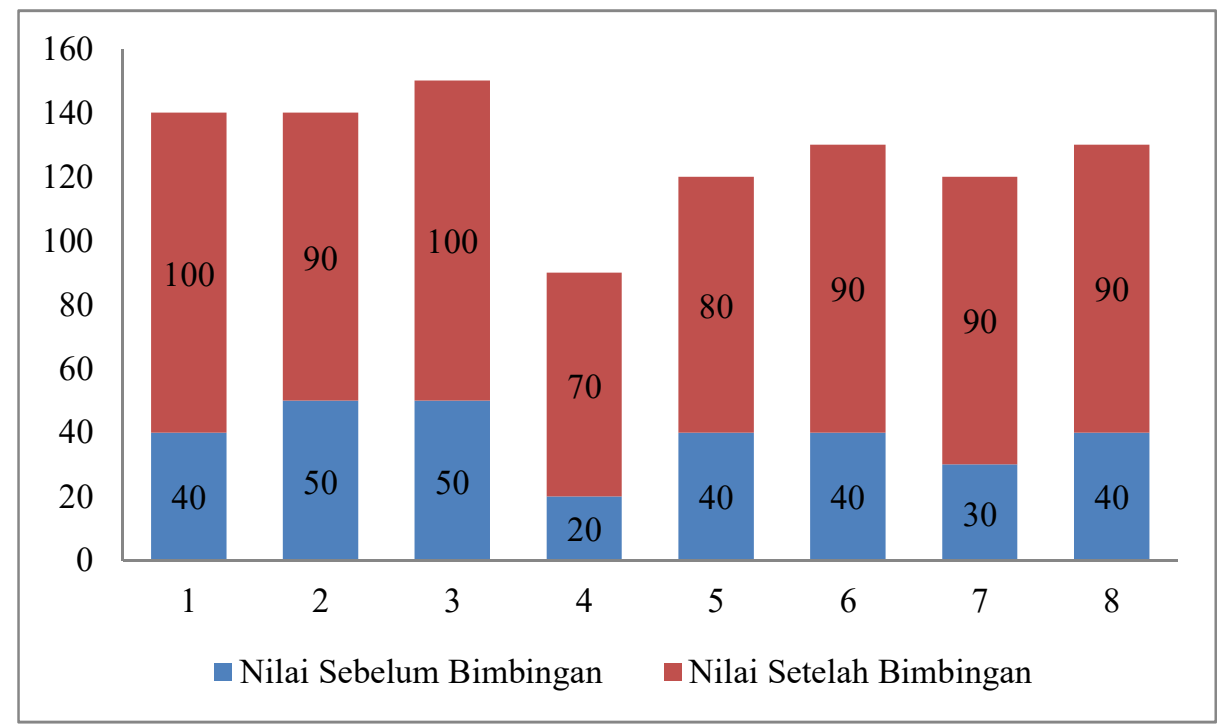

Gambar 3. Grafik hasil analisis kemampuan peternak ayam lokal sebelum dan setelah bimbingan teknis IB pada unggas

Hasil ini uji t (Tabel 1) menunjukkan bahwa nilai statistik t yang diperoleh adalah 8,9806, dan nilai p-value pengujian adalah 5,65E-07. Dengan menggunakan kaidah pengambilan keputusan berdasarkan $p$-value, pada $\alpha=0.05$. -8,9806, $<5,65 \mathrm{E}-07$. Dengan demikian dapat dijelaskan bahwa rata-rata nilai sebelum bimbingan teknis IB unggas dan setelah dilakukan bimtek terdapat perbedaan. Terjadi peningkatan nilai ujian rata-rata $50 \%$ setelah kegiatan bimbingan teknis. Hal ini menunjukkan terjadinya peningkatan pemahaman masyarakat yang cukup signifikan setelah diadakannya kegiatan ini. Hal ini diharapkan merangsang peternak ayam buras di kecamatan Watubangga dapat mengadopsi inovasi teknologi IB ini untuk peningkatan mutu genetik ayam lokal. 
Peningkatan Keterampilan Budidaya Ternak Unggas Bagi Peternak Ayam Lokal di Kabupaten Kolaka Melalui Bimbingan Teknis Inseminasi Buatan dan Metode Persilangan

Junaedi, Khaeruddin, Abdul Hakim Fattah

Menurut Rogers (1983), tahapan adopsi seseorang tersebut dimulai dari tahap kesadaran (awareness), yaitu tahap seseorang tahu dan sadar ada terdapat suatu inovasi sehingga muncul adanya suatu kesadaran terhadap hal tersebut. Tahap keinginan (interest), yaitu tahap seseorang mempertimbangkan atau sedang membentuk sikap terhadap inovasi yang telah diketahuinya tersebut sehingga ia mulai tertarik pada hal tersebut. Tahap penilaian (evaluation), yaitu tahap seseorang membuat putusan apakah ia menolak atau menerima inovasi yang ditawarkan sehingga saat itu ia mulai mengevaluasi. Tahap mencoba (trial), yaitu tahap seseorang melaksanakan keputusan yang telah dibuatnya sehingga ia mulai mencoba suatu perilaku yang baru. Tahap adopsi (adoption), yaitu tahap seseorang memastikan atau mengkonfirmasikan putusan yang diambilnya sehingga ia mulai mengadopsi perilaku baru tersebut. Meskipun pada pengabdian masyarakat ini masih pada tahap mencoba (trial), namun tidak menutup kemungkinan dapat berlanjut ke tahap adopsi.

\begin{tabular}{lrr} 
t-Test: Two-Sample Assuming Equal & \\
Variances & & \\
& & \\
& & \\
Mean & 38,57143 & 87,14285714 \\
Variance & 114,2857 & 90,47619048 \\
Observations & 7 & 7 \\
Pooled Variance & 102,381 & \\
Hypothesized Mean Difference & 0 & \\
Df & 12 & \\
t Stat & $-8,9806$ & \\
P(T<=t) one-tail & $5,65 \mathrm{E}-07$ & \\
t Critical one-tail & 1,782288 & \\
P(T<=t) two-tail & $1,13 \mathrm{E}-06$ & \\
t Critical two-tail & 2,178813 & \\
\hline
\end{tabular}

Tabel 1. Hasil Uji Perbedaan Nyata (Uji t) analisis kemampuan peternak sebelum dan setelah bimtek IB pada unggas

\section{Metode Persilangan Ayam Lokal}

Program perbaikan mutu genetik ternak ayam lokal di Kabupaten Watubangga dilakukan dengan teknik persilangan luar (cross breeding). Persilangan luar merupakan perkawinan antara hewan jantan dan betina dari dua ras yang berbeda. Tujuan persilangan ini adalah untuk mendapatkan keturunan dengan sifat-sifat baru. Kawin silang antara dua 
rumpun ayam yang berbeda telah terbukti dapat meningkatkan performa ayam lokal (Tricahyadi, 2012).

Program persilangan luar bertujuan untuk perbaikan genetik sehingga dihasilkan ayam dengan produktivitas yang lebih baik. Hal ini dapat dicapai karena terdapat pengaruh individual direct genetic effect, maternal dan paternal effect serta individu heterosis. Program persilangan yang dilakukan dengan menyilangkan jenis ayam kampung dengan ayam bangkok serta menyilangkan ayam tolaki dengan ayam pelung. Hasil persilangan keduanya saling disilangkan hingga dihasilkan ayam yang mewarisi sifat dari keempat jenis ayam tersebut (Gambar 4). Sifat yang diinginkan dari ayam bangkok dan pelung adalah bobot badan yang tinggi, sedangkan sifat yang diinginkan dari ayam kampung dan tolaki adalah ketahanan terhadap penyakit dan daya adaptasi yang tinggi.

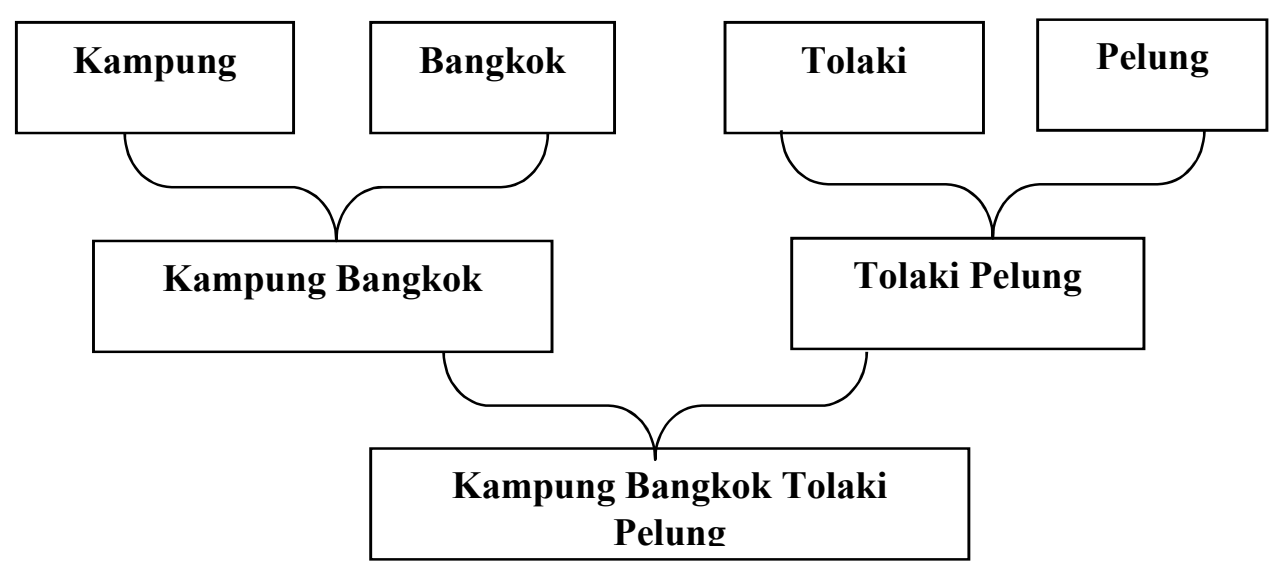

Gambar 4. Skema Program Persilangan Ayam Lokal di Kabupaten Watubangga

\section{KESIMPULAN}

Bimbingan teknis inseminasi buatan pada peternak ayam Bangkok di Kecamatan Watubangga Kabupaten Kolaka menyebabkan terjadinya peningkatan pengetahuan masyarakat mengenai inseminasi buatan pada unggas sebesar $50 \%$.

\section{DAFTAR PUSTAKA}

Badan Pusat Statistik. 2016. Populasi Ternak Unggas Menurut Jenis ternak dan kecamatan di kabupaten Kolaka. https:/kolakakab.bps.go.id /statictable/2017/12/19/552/populasi-ternak-unggas-menurut-jenis-ternak-dankecamatan-di-kabupaten-kolaka-2016.html. Diakses 2 Maret 2021.

Ginting, M. (2002). Strategi komunikasi bagi penyuluh pembangunan. Medan: DEP SEP FP USU. 
Irastuti. (2011). Pengaruh bangsa pejantan dan interval deposisi sementerhadap keberhasilan inseminasi buatan pada ayam. Jurnal Sains dan Teknologi Tadulako. $1(1), 13-25$.

Iskandar S. 2007. Tatalaksana pemeliharaan ayam lokal. Di dalam: Sulandari S, Zein MSA, Paryanti S, Sartika T, Sidadolog JHP, Astuti M, Widjastuti T, Sujana E, Darana S, Setiawan I et al., editor. Keanekaragaman Sumber Daya Hayati Ayam Lokal Indonesia. Jakarta: LIPI Pr.

Kismiati S. (1999). Fertilitas telur dan mortalitas embrio ayam kedu hitam pada interval inseminasi yang berbeda. Jurnal Pengembangan Peternakan Tropis. Edisi khusus, 51-55.

Rogers, E. M. (1983). Diffusion of innovations. London: The Free Press.

Suprijatna, E., Sunarti, D., Atmomarsono, U. \& Sarengat, W. (2012). Kesiapan Bahan Pakan dalam Mendukung Pengembangan Unggas Lokal. Dalam: Prosiding Workshop Nasional Unggas Lokal.Pusat Penelitian dan Pengembangan Peternakan.Badan Penelitian dan Pengembangan Pertanian, Kementerian Pertanian, Jakarta.

Tricahyadi, W. (2012). Estimasi nilai heritabilitas fertilitas, daya tetas, dan berat badan ayam hasil persilangan ayam pelung dan broiler. Tesis. Universitas Gadjah Mada. 